\title{
Lumen
}

Selected Proceedings from the Canadian Society for Eighteenth-Century Studies

\section{Moral Correction: The Refusal of Revision in Henry Fielding's Amelia}

\section{Adam Budd}

Volume 20, 2001

URI : https://id.erudit.org/iderudit/1012299ar

DOI : https://doi.org/10.7202/1012299ar

Aller au sommaire du numéro

Éditeur(s)

Canadian Society for Eighteenth-Century Studies / Société canadienne d'étude du dix-huitième siècle

ISSN

1209-3696 (imprimé)

1927-8284 (numérique)

Découvrir la revue

Citer cet article

Budd, A. (2001). Moral Correction: The Refusal of Revision in Henry Fielding's Amelia. Lumen, 20, 1-17. https://doi.org/10.7202/1012299ar

Copyright (c) Canadian Society for Eighteenth-Century Studies / Société canadienne d'étude du dix-huitième siècle, 2001
Ce document est protégé par la loi sur le droit d'auteur. L'utilisation des services d'Érudit (y compris la reproduction) est assujettie à sa politique d'utilisation que vous pouvez consulter en ligne.

https://apropos.erudit.org/fr/usagers/politique-dutilisation/ 


\section{Moral Correction: The Refusal of Revision in Henry Fielding's Amelia}

'I made the same observation,' cries Booth: 'sure some Misfortune hath befallen her.' 'A Misfortune indeed!' answered Amelia, 'sure Child, you forget what Mrs. Ellison told us, that she had lost a beloved Husband. A Misfortune which I have often wondered at any Woman's surviving,' - at which Words, she cast a tender Look at Booth, and presently afterwards throwing herself upon his Neck, cried - 'O Heavens! What a happy Creature am I; when I consider the Dangers you have gone through, how I exult in my Bliss!' The good natured Reader will suppose that Booth was not deficient in returning such Tenderness, after which the conversation became too fond to be here related. (Amelia 204-205) ${ }^{1}$

Captain William Booth and his wife Amelia know that they cannot escape the constraints imposed on them by London's sinister justice system and its roving bands of mercenary bailiffs. Yet the hopelessness of the situation provides a special impetus for Amelia, 'the most worthy, generous, and noble of all Human Beings,' to reflect positively on her predicament (89). Nothing, it seems, might renew Amelia's affections for her husband more effectively than a sentimental reflection on another's misfortunes. Indeed, the psychological pressure that social injustice exerts in this novel makes it nearly impossible for Amelia to take action to improve her circumstances without first considering - and, at times, imaginatively reenacting - the stories told to her. For our instructive paragon, the qualities of life afforded by 'Fortune' or 'Providence' always demand an appreciation of another's suffering before they can be understood as bearing implications for understanding her own. ${ }^{2}$ It is this emphasis on the moral function of imagined relationships that leads Fielding to mention the fond scene to his reader without proceeding to describe it.

In contrast, Amelia's 'jealous Rival,' Miss Mathews, encourages Booth to narrate his past, and thus reflect on his family's suffering, merely so she can perform the role of a sentimental listener whose emotional investment in others will improve herself $(161,164)$. When Mathews senses another's misfortune, the experience leads her to increase her own 
involvement in the storytelling, but this causes her moral and æsthetic decline: she will later use the fact of the illicit sexual encounter with Booth to blackmail him to extend the liaison, even as this coercion diminishes her status in the novel and in Booth's life. Before Miss Mathews responded to Booth's story through her demand to extend the romance, she enjoyed the status of an interactive confidante, a textual equal to Booth for the first four books of the History. After her demand, she moves to the periphery of the novel and of Booth's life: she becomes, in effect, merely a vague nuisance to his conscience, a character who will henceforth speak only through ill-conceived letters, the disguised voice of a masque in a shepherdess' costume, and later a frantic woman in the street who implores Booth to join her for supper $(164,225,417,486)$. The quality of this æsthetic and textual decline enables Fielding to offer his readers a realistic portrait of the city, its prison, and its sponging-houses, in all their explicit squalor and viciousness, a contemporary realism without precedent in commercial English fiction.

It is through this portrait of contemporary London and its unpredictably lecherous patrons, merciless bailiffs, and volatile magistrates, that Fielding proposes his most didactic fictional project to date, in which 'we shall best be instructed in this most useful of all Arts, which I call the ART of LIFE' (17). The novel's first chapter pays a surprisingly open compliment to Samuel Richardson's earnest claims to defend (or construct) moral territory, a gesture that has led critics to suspect that in their last novels 'the two rivals were tacitly adopting characteristic features of each other's writing' (Sabor 3). The novel could also be assessed as a literal prescription from its author, who may have 'used Amelia to expose those glaring public and private evils which were beyond [Fielding's] authority as a magistrate to correct' (Battestin, A Life 544). Surely the novel does distinguish itself through an innovative combination of debts to established literary genres, and it does perform what Claude Rawson calls a 'retrospective reversal' of the gregarious and more familiar 'comic Epic-Poem in Prose' (150). Yet, Fielding's novel also provides an ironic commentary on representations of sentimental interaction as they were enacted through Richardson's means of moral correction and theorized in David Hume's contemporaneous philosophy. The basis of what Robert Alter has called Fielding's 'whole didactic weakness' derives from an innovative poetics that indicates the lucid personal stakes of social corruption while it allows a certain ambiguity and ironic self-reflexivity that might challenge the reader to question fiction's ability to improve the reader's moral conduct (163). ${ }^{3}$

In this special sense, which implies a crucial consequence of the novel's formal construction as well as its thematic features, Amelia is more a critical commentary on Richardson's claim that the novel's drama 
'should be considered as little more than the Vehicle to the more necessary INSTRUCTION' than it is an attempted embodiment of it (Clarissa 1 , vi). ${ }^{4}$ When Miss Mathews deteriorates as a consequence of her attempt to use the sentimental means of moral improvement for manipulative ends, the troubling realism that this entails shows that the workings of poetic justice - or of attentive ideal readers - will not correct the facts of social distress.

In a letter dated 10 May 1748, before the final three volumes of Clarissa were even printed, Richardson announced that he intended to rewrite his novel in an effort to correct his readers' interpretations of it, a rewriting which might well be 'the earliest example of the effect upon a novel of audience reactions in the course of publication' (KinkeadWeekes 157). Richardson's persistent desire to correct and revise his novel, this suggestion that textual amendment improves moral judgment, provides a commentary on that novel's didactic method especially when we compare Richardson's release of Letters and Passages Restored from the Original Manuscripts of the History of Clarissa with Fielding's promise, which he made in the midst of a barrage of lucid critical hostility over Amelia: 'to trouble the World no more with any Children of mine by the same Muse,' a vow he made within weeks of the novel's release (Covent-Garden 28 Jan. 1752, 66). Fielding's peremptory declaration not to revise Amelia, or even to write another novel again, represented an audacious and very public departure from Richardson's means of moral communication. ${ }^{5}$ The relationship between these two editorial decisions operates on both a stylistic and a conceptual level, and discussing its complexity might help us recognize the extent to which Fielding's choice reveals an innovative engagement with a controversial theory of moral sentiments that Hume was trying to validate throughout the 1740s.

In an address 'to lead the common Reader into some tolerable conception of the nature of this Work and the design of its Author,' the Preface to the fourth volume of the first edition of Clarissa declares that the author intends to offer 'Directions for [the reader's] Conduct, or Employment for his Pity, in a HISTORY of LIFE and MANNERS, where, as in the World itself, we find Vice, for a time, triumphant, and Virtue in distress' $(4, \mathrm{iv}){ }^{6}{ }^{6}$ Whereas Richardson makes strident efforts to remind his readers that the act of interpretation is itself an indication of moral judgment in the real world of actions, where the task of fiction is to delineate Vice and Virtue with prescriptive clarity, Fielding encourages us to realize that the moral quality of interpretation derives from an 
eternally complex relationship between Vice and Virtue. Moreover, Fielding suggests that this dynamic relationship might not represent itself with certainty in a work of fiction nor be settled through our sentimental response to it. Fielding's avowed promise not to publish another novel assured that the ambiguities of Amelia, through this implicitly defiant answer, would provoke and continue to question the link between the public figure of the court magistrate and his complex literary representations of moral conduct. It also capitalizes on his readers' moral ambivalence as a means of 'promoting the Cause of Virtue.' Richardson responded to public misinterpretation with a determination to school his readers in specific principles by printing two revised editions of Clarissa within three years of its first release and by sending this 'restored' material free of charge to all paid subscribers of the first edition. Toward the end of his career he assembled A Collection of the Moral and Instructive Sentiments, Maxims, Cautions, and Reflections Contained in the Histories of Pamela, Clarissa, and Sir Charles Grandison 'in order to render these Letters more completely useful' (Collection vii). No one in the century, it would seem, made a more convincing or public effort to uphold Samuel Johnson's demand that in fiction, 'vice, for vice is necessary to be shewn, should always disgust; nor should the graces of gaiety, or the dignity of courage, be so united with it, as to reconcile it to the mind' (Rambler 4; Works 2, 20). A revealing complexity arises when we explore the stylistic evocations of Clarissa in Amelia, and wonder why Fielding seemed to require references to Richardson as a means to promote his own theory of the relation between readerly experience and moral conduct.

Perhaps the most important formal difference between the two novels derives from the extent to which writing - careful, ostensibly private, yet as Lovelace declares, 'written to the moment' - substitutes for actual speech in Clarissa $(4,288)$. The composition, delivery, discovery, and interpretation of letters play an important role in Amelia as well; however, unlike Clarissa, where letters provide the sole means of representing dialogue, history, and voice, the letters in Fielding's novel fulfill a delayed and secondhand didactic function. The epistolary mode renders Richardsonian conversation indistinguishable from writing, since all speech in Clarissa is subjected to the limitations and capabilities inherent in the process of composing and interpreting the letter. Moreover, the epistolary conversations that comprise Clarissa define a historian's role for the novel's 'Editor': he is technically indispensable as the organizer of the letters, and this enables him to represent fictional actions as examples of the private conduct of real people. As Linda Kauffman has argued, 'writing is Clarissa's crime and her punishment': Richardson presents letter-writing as the most obvious and precise example of 
private and public behavior (132). Richardson's editorial position also, of course, allowed him to rewrite the text and represent this revision as the 'restoration' of material. In direct contrast, writing in Amelia exacts a delayed didacticism, since the letters in Fielding's novel are read, interpreted, and introduced by the characters before the narrator comments on them; they offer only one example of public and private conduct among many, including verbal conversation, messages whispered to servants, and stories told to children. Amelia is narrated entirely from a retrospective vantage point and the narrator suggests that his actual friendships with the novel's characters disable him from having a superior command of their private histories. This posture openly prevents him from providing us with an effective, let alone editorial, moral guide to the History.

In the 'Hints of a Preface to Clarissa,' Richardson provides a lucid explanation for the eventual destruction of his heroine: 'Clarissa takes but one false Step in the whole Piece ... but this single Step was of the utmost Consequence' (Brissenden 10). Leo Braudy's sense that Fielding's construction of Miss Mathews evokes the rhetoric of Richardsonian iron-chain causality' may be well justified, but Fielding's evocations of Richardson serve an ultimately satirical agenda that demands a more subtle response on the part of the literate reader (205). One of the first letters we encounter in Amelia is written by Betty Harris, Amelia's older unmarried sister, who deceives Amelia in an effort to conceal their mother's wish for Amelia to inherit the family fortune. This letter suggests an outright imitation of Richardson on Fielding's part:

My Mamma being much disordered, hath commanded me to tell you, she is both shocked and surprised at your extraordinary Request, or, as she chuses to call it, Order for Money. You know, my Dear ... that your Marriage with this Red-coat Man was entirely against her Consent, and the Opinion of all our Family, (I am sure I may include myself in that Number) and yet after this fatal Act of Disobedience, she was prevailed on to receive you as her Child; not, however, nor are you so to understand it, as the Favourite which you was before. (121)

This evident signal to Richardson's first edition of Clarissa, the only edition in which Clarissa refers to her mother with the more aristocratic 'Mamma' and not middle-class 'Mother,' which she will use in subsequent editions, succeeds as an ironic commentary on the iron-chain theory of causality. ${ }^{8}$ Richardson intends to defend the view that Clarissa's false step and crucial lapse in her otherwise exquisite judgment is largely responsible for her eventual demise; he famously indicates in the Preface that 'it is one of the principal Views of the Publication, to caution ... Children against preferring a Man of Pleasure to a Man of 
Probity'; and in his correspondence he states clearly that while 'My Girl is thought over nice by many ... I would that she should have some little things to be blamed for' (Clarissa 1, viii, Selected Letters 88). Elsewhere, Richardson remarks to one of his more critical friends: 'I must say, that I humbly think, sufficient Attention is not given to her being so roughly impelled, so impoliticly driven, into the Power of a Man she must, and I thought apparently would, more probably have avoided' (Selected Letters 81). Betty Harris's letter, on the other hand, satirizes this fixed-link logic through the novel's ultimate revelation that Harris is lying to Amelia to conceal her own forged and botched claim to the family fortune. The evocation of Richardson here suggests that the rhetoric of naïve causality betrays a simple-minded and self-incriminating justification of nothing more than a jealous fantasy. In Amelia this strategy does not permit or explain the destruction of the heroine; it merely embarrasses the exiled older sister whose folly leads to the restoration of the heroine's fortunes. The Richardsonian devices which rely on literal prescription offer us a specifically ironic instruction.

Miss Mathews provides another example of Fielding's playful borrowing of Richardsonian rhetoric when, in the very act of seducing a married man, she echoes Richardson's paternal admonitions: 'what is called being upon a good Footing is, perhaps, being upon a very dangerous one; and a Woman who hath given her Consent to marry, can hardly be said to be safe till she is married' (53). Mathews's words of illusory wisdom eventually descend into what at first appears to be the recital of a tragic melodrama, the climax of which describes her in a fit of jealous rage, stalking and then stabbing her ex-suitor with a penknife because he has married someone else. Her description of the event offers an exact reversal of the circumstances surrounding Clarissa's threat to her own life, the famous penknife scene at Mrs. Sinclair's (cf. Clarissa 5, 340-345). Mathews narrates the prelude to her story thus:

Scarce had I recovered the Use of my Senses, when I received a Letter from the Villain, declaring he had not Assurance to see my Face, and very kindly advising me to endeavour to reconcile myself to my Family; concluding with an Offer, in case I did not succeed, to allow me twenty Pounds a-Year to support me in some remote part of the Kingdom. (59)

In Fielding's treatment, Miss Mathews's frenzied attempt on Hebbers's life expresses a proud wish for revenge - 'for this Fact I am ready to die, and shall with Pleasure receive the Sentence of the Law' - a wish that evokes the theatricality of burlesque farce; Booth can hardly contain his revulsion and his laughter when the story is told to him (59). Yet, were we to consider the presumed source and most direct influence on the 
penknife scene, or interpret the conversation in the hypothetical context of an epistolary exchange, Booth would be compelled to express his response in the measured language of a polite yet private correspondence and the comedy would quickly deflate: for how might the confession of violent acts be comedic when it appears in private letters? As readers of Clarissa as well as Amelia, we realize that had Booth married Mathews instead of Amelia (Mathews claims maliciously that he was her first choice), none of this violence, distress, and imprisonment would have taken place. The analogy to the famous penknife scene in Clarissa proposes a deeper reflexive commentary on Fielding's dramatic purposes: when Clarissa threatened to stab herself, the desired effect was to move her captors to fear the consequences of her violence, while it enacted, in a moment of masochistic desperation, the shame and helplessness brought on by her surviving the rape. Miss Mathews might be trying to affect Booth's sympathies by describing her own penknife scene in such close histrionic detail, but the desired dramatic effect fails, and the actual experience brands Mathews as just one more of Justice Thrasher's doomed parties, pathetically and carelessly sentenced to imprisonment in Newgate. Fear of her violent temper further encourages Booth to avoid any subsequent contact with her; hence any masochistic desire on Mathews's part indeed succeeds, but we know enough about Mathews at this point to conclude with confidence that her scheme is highly self-conscious, and her story most likely a calculated exaggeration. By allowing the dynamics of violence and seduction to account for a complexity of intentions and consequences, where our hero is a culpable agent, Fielding both shows and elicits a sentimental enactment of morally ambiguous values.

\section{II}

Although we may not find any explicit references to David Hume in Fielding's novels, journalism, or letters, we know that Fielding owned a first edition of Hume's Philosophical Essays concerning Human Understanding (Thornbury 185). Fielding probably received his copy of Hume from Andrew Millar, his own publisher and close friend, who was also printing Hume's works between 1748 and 1768. The 1748 edition of the Philosophical Essays concerning Human Understanding, whose title audaciously evokes Locke's treatise, is a short collection of interconnected essays that explicate the empiricist premises Hume introduced in his magisterial yet professedly 'dead-Born' Treatise of Human Nature (173940 ) and would refine three years later in the more succinct Enquiry concerning the Principles of Morals (1751). ${ }^{9}$ In a direct challenge to Richard- 
son's notion of moral judgment and to Locke's natural law theory, Hume iterates throughout the Philosophical Essays that 'the active principle can never be founded on an inactive,' that reason (an inactive faculty of judgment) cannot control the passions (an active function of natural impulse). This suggests that the moral content of any action cannot be shown by citing one's allegiance to laws, since the primary adherence of an action is to the passionate desire to perform acts that feel right, or give rise to a 'pleasing sentiment.' More provocatively, the argument also proposes that since intentions are the operative cause and action their physical effect, 'every Argument deduced from Causes to Effects must of Necessity be a gross Sophysm [sic]; since it is impossible for you to know any thing of the Cause but what you have, antecedently, not inferr'd, but discover'd to the full, in the Effect' (Philosophical 218). Morality, then, is not a quality inherent in an action. To attribute a moral intention on the basis of evaluating an action as just, is in fact a case of chimerical projection on the spectator's part, since actions themselves cannot contain a practical basis to prove a virtuous intention: Hume concludes that 'morality is determined by sentiment [and] virtue [is] whatever mental action or quality [which] gives to the spectator the pleasing sentiment of approbation' (Enquiry 261). Hume invokes Locke's ethical rationalism when he offers a derisive lament for the times when

all Morality was suppos'd to be built on eternal and immutable Relations, which to every intelligent Mind were equally invariable as any Proposition concerning Quantity or Number. (Philosophical 14-15) ${ }^{10}$

Later, Hume states his position directly:

It seems to me, that the only Object of ... Demonstration is Quantity and Number, and that all Attempts to extend this more perfect Species of Knowledge beyond these bounds are mere Sophistry and Illusion. (252)

The thesis culminates in a proposal that turns away from social evaluation of moral good toward a discussion of the subjective desire to enact the sentimental fantasies that themselves motivate moral decisions. It is this emphasis on the spectator's desire for a self-confirming pleasure that troubles a theory of sentiment which would try to shape and then reshape the text as a way to improve the reader. For Hume, not only is morality defined solely through an analysis of the sentiments themselves, apart from their practical ends, but moreover the cultivation of moral judgment is beyond the didactic reach of any particular æsthetic experience. 
In Amelia, as in Hume's moral writings of the 1740s, Fielding shows that eternal and immutable relations might never be a reliable gauge of one's virtue; but by enacting a sentimental interest, however morally unpredictable it might be, we can locate the kind of 'active' psychological wish that motivates people's intentions to act, a wish that is necessarily subject to turbulent and confused social contexts and means of interpretation. A faith in one's ability to predict actions based on a presumed knowledge of inclination is terribly dangerous, as Booth seems doomed to demonstrate. Fielding's interest lies in the recurrent and costly experience of misinterpretations and the seemingly unending disappointments which force his characters to recognize that one's moral qualities do not reveal themselves through any particular code of conduct or demonstrable social allegiance. The conceptions of morality arise, instead, through one's empirical reflections on another's customary conduct that announce one's own moral values: a reflection based on experience and its practical consequences, not on attempts to project or infer the moral function of inclinations. This might have been Richardson's primary motivation when he chose to use fiction to correct moral conduct. However, the response of his readers, like Fielding's, showed him that no literary experience can guarantee any particular sentimental response. Moreover, Fielding's novel articulates its own critique of natural law theory through its insistence that no adherence to any maxim, however outwardly virtuous, will guarantee a convincing reward in the novel's dénouement. Although Amelia and Booth are united in the end, the enormous inheritance that is unexpectedly bestowed on the couple in the novel's final ten pages seems to equate financial success with domestic happiness, the text's final yet certainly contradictory lesson.

Even though the narrator in Amelia opens the novel with pretensions to improve his reader, by the end of the novel the delayed didactic function of his characters' stories enables him to live contiguously with his fiction, or to bring his History into reality. Just as he 'brings our History to a Conclusion,' he underlines this puzzling assertion of his equivalent textual status:

Amelia declared to me the other Day, that she did not remember to have seen her Husband out of Humour these last ten years; and upon my insinuating to her, that he had made her the best of Wives, she answered with a Smile, that she ought to be so, for that he had made her the happiest of Women. $(531,533)$

Fielding's flippant suggestion here of friendship with the novel's characters serves as a mimetic middle ground which is highly evocative of the 'Conclusion' to the fourth volume of Richardson's Clarissa, where the 
connection between the author and his characters seems too casual and incidental to offer a 'HISTORY of LIFE and MANNERS, where, as in the World itself, we find Vice, for a time, triumphant, and Virtue in distress.' At the same time, the relationship is sufficiently realistic to warrant a democratic invitation for us to make an empirical comparison of ourselves with the novel's characters, one which is not mitigated or controlled by any author or literary friend.

\section{III}

In January 1746/7, Richardson might have borrowed Fielding's terminology when he referred to his own 'Scribbling' as 'a New Species of Writing,' a rhetoric he used when confiding to his friends the problems he faced while developing the plot structure of Clarissa. He implied a contrast to the more complex notions of readerly reception that would be elicited by Amelia:

I never had the Assurance to think it any-thing extraordinary - Only knew my Intention; and thought the Stories might do some Good, if not ill-received. (Selected Letters 78)

Yet the Preface to Clarissa (which was first published in December 1747) seems to suggest that Richardson had heeded the advice of his friends and may have given up on providing an entertaining story. Certainly, by this time he had been fearing the pedagogical complications of a dramatic 'Amusement':

They were of the Opinion, That in all Works of This, and of the Dramatic Kind, STORY, or AMUSEMENT, should be considered as little more than the Vehicle to the more necessary INSTRUCTION. (Clarissa 1 , vi)

Whereas Richardson struggles through his plot to maintain a clear didactic appeal to upholding a particular moral standard, Fielding remains editorially silent in order to emphasize that his protagonists require shortcomings, paradoxes, and even failures to support his final didactic project.

With respect to his narrative epistemology, Fielding draws an implicit analogy between himself and Hume through his decisive departure from Richardson's means of publicizing his elaborate attempts to editorialize and control his readers' interpretive experience: the publication history of Clarissa offers us a model of Lockean insistence on maintaining what Clarissa herself calls 'the course I shall be permitted or be forced 
to steer [when] I must be considered, a person out of her own direction' (Clarissa 2, 138). When Locke tries to reconcile his empiricist convictions with his Christian faith, he requires an embodiment of 'reason, our last Judge and Guide in everything' to help him divide enthusiastic ideas from those derived from divine revelation (4.19.3-4, II 431). Richardson, too, appears determined to give a clear direction for his readers when their impassioned sympathies become confused. As editor, Richardson tries to clear up didactic ambiguities and maintain the tradition of what Michael McKeon calls 'naïve empiricism' that 'involves a dependence on received authorities and a priori traditions' where, even for Locke, observers require 'a new set of discoveries communicated by God to establish their opinions and regulate their conduct' (McKeon 21, Locke 4.19.3-4, II 431). Through the guise of editor, Richardson tries to define our quality of belief regarding the testimony of fictional figures who are represented in his novels as paradigmatic, instructive, real people. Perhaps this is the reason why Richardson, unlike Fielding, never named himself in his novels nor named others as beneficiaries of a dedication. Such an overt self-disclosure might have revealed his primarily creative, and hence not transcendently authoritative, corrective role. The analogy between Richardson and Locke provides a revealing contrast, I think, to Fielding's thematic and metafictional embrace of Humean ambiguity and skepticism.

Richardson discovered as early as October 1748 (before the release of the novel's final installment) that his villain, Lovelace, was being admired for his charm, that the 'principal Views of the Publication' were being threatened by a miscomprehending audience: 'it has been a matter of surprise to me,' Richardson writes politely to Lady Bradshaigh, 'and indeed of some concern, that this character has met with so much favour from the good and virtuous,' including Bradshaigh herself (Clarissa 1, viii; Correspondence 4, 187). This led directly to Richardson choosing to issue for free the revised Letters and Passages Restored to the Original Manuscripts of the History of Clarissa to all purchasers of the first edition. Fielding, on the other hand, requires Booth's gentlemanly failings - his sexual infidelity, irresponsible gambling, and reluctance to confess his guilt - to substantiate his heroism, even though these failings are never subjected to a proven reformation. Booth's attachment to unchristian codes of conduct indeed seems so nearly Mandevillian that when this is suggested to him, Booth must explain in detail that in fact his values should not be so termed (114-115). Without these deficiencies and the abundant examples of their unfortunate results, Fielding would not be able to integrate his experience of social injustice into a novel that engages directly with actual legal controversies. Even as Fielding professes his intentions 'to promote the Cause of Virtue, and to expose some 
of the most glaring Evils, as well public as private, which at present infect the Country,' he has allowed Amelia to address, as Martin Battestin has noted, 'a sensationalist psychology' that threatens 'conventional Christian humanism' even as the novel represents 'a theory of human nature virtually indistinguishable from the psychology it ostensibly repudiates' (3, 'Problem' 616, 635). It is this quality of moral incompatibility with social realism that invites the reader's sentimental enactment of this drama in the imagination as a means to promoting virtue, one which cannot be solved by an authorial demand for poetic justice. When Amelia herself realizes her virtue rewarded at the novel's close, the reward is not for her conduct - she in fact performs few actions in the course of the novel - but for her inclinations, the ambiguities of which continue to lead critics to censure Fielding's conferral of a poetic justice at the novel's 'Conclusion.' Booth's reformation is a straightforward and instantaneous response to reading, a turn in sentiment that is merely declared and not enacted:

'You say you have had your Doubts, young Gentleman, indeed I did not know that - And pray, what were your Doubts?' 'Whatever they were, Sir,' said Booth, 'they are now satisfied, as I believe those of every impartial and sensitive Reader will be, if he will, with due Attention, read over these excellent Sermons.' (511)

No one else in Fielding's realistic novel finds a miraculous restoration through a renewed appreciation of Christian writings, and in the same way Fielding's novel will not try to cement the link between sentimental experience and moral conduct. George Sherburn has referred to Booth's swift conversion to Christian humanism in the novel's final pages as 'a supernatural intervention' that does not deserve its reward (151). The vivid characterizations of suffering and depravity somehow defy the attempted closure of Fielding's conclusion, and they problematize Dr. Harrison's solemn moment with Booth at the end of the novel in which he asserts that 'Providence hath done you the Justice at last, which it will one day or other render to all Men' (522). As Ronald Paulson has pointed out, the ending is negligible in its literal resolution: '[Amelia's London] society remains as corrupt at the end as at the beginning' (Satire 163). After we learn of a repentant thief's religious reformation, we learn that Robinson has 'returned to vicious Courses,' has been apprehended for stealing a handbag, and has been hanged at Tyburn: a formulaic sequence that supports Fielding's view: 'so apt are Men, whose Manners have been once thoroughly corrupted, to return, from any Dawn of an Amendment, into the dark Paths of Vice' (532). We might wonder whether this maxim will apply to Booth after his own amendment from gambling, adultery, atheism, and material extravagance: this final devel- 
opment in the plot complicates Fielding's representations of heroic action when we feel tempted to read these as moral prescriptions in the tradition of sentimental writing.

Perhaps no other novel of eighteenth-century England offers the unpredictability, unconventionality, and yet avowedly serious moral intent of Amelia, Fielding's final sustained work of fiction: the controversial link between poetic justice and sentimental involvement, where readers would confront the realistic fact of social injustice without the editorial protection of a convincing moral revision, offers a decisive challenge to Richardson by pointing to the unresolved details of social injustice that defy narrative correction. The refusal to revise, qualify, or continue Amelia provides an important analogy to its hero and heroine's urban plight whose troubling story merges with its own retelling. The task of writing this novel showed Fielding defending the innovative notion that moral correction through textual revision will not enact the sentimental engagements which are the most effective means of promoting the cause of virtue.

\section{ADAM BUDD}

\section{Works Cited}

Alter, Robert. Fielding and the Nature of the Novel. Cambridge, MA: Harvard U P, 1968.

Battestin, Martin C. with Ruthe R. Battestin. Henry Fielding: A Life. London: Routledge, 1989.

'The Problem of Amelia: Hume, Barrow, and the Conversion of Captain Booth.' English Literary History 41 (1974): 613-648.

Braudy, Leo Beal. The Narrative Stance. Ann Arbor: U Microfilms, 1968.

Conway, Alison. 'Fielding's Amelia and the Esthetics of Virtue.' Eighteenth-Century Fiction 8 (1995): 35-50.

Dudden, F. Homes. Bibliography. Vol 2. Henry Fielding: His Life, Works, and Times. Oxford: Clarendon P, 1952. 2 vols. 1126-1157.

Fielding, Henry. Amelia. 1751. Ed. Martin C. Battestin and Fredson Bowers. Oxford: Clarendon P, 1983.

. The Covent-Garden Journal and A Plan of the Universal Register-Office. 1751-52. Ed. Bertrand A. Goldgar. Middletown, CT: Wesleyan U P, 1988. Joseph Andrews and Shamela. Ed. Arthur Humphreys. London: Dent, 1993.

The Life of Jonathan Wild the Great. 1743. Ed. David Nokes. Harmondsworth: Penguin, 1986. 
Hume, David. An Enquiry concerning the Principles of Morals. 1751. Ed. Thomas Hill Green and Thomas Hodge Grose. Essays Moral, Political, and Literary. Vol 1. London: Longmans, Green, 1874. 2 vols. 167-307.

The Letters of David Hume. Ed. J.Y.T. Greig. Oxford: Clarendon P, 1932. 2 vols.

. Philosophical Essays concerning Human Understanding. London: Printed for A. Millar, 1748 .

. A Treatise of Human Nature: Being an Attempt to introduce the experimental Method of Reasoning into Moral Subjects. 1739-40. Ed. P. H. Nidditch. Oxford: Clarendon Press, 1978.

Johnson, Samuel. The Works of Samuel Johnson. Oxford: Talboys and Wheeler, 1825. 9 vols.

Kauffman, Linda S. Discourses of Desire. Ithaca: Cornell U P, 1986.

Kinkead-Weekes, Mark. 'Clarissa Restored?' Review of English Studies New Series 10 (1959): 156-171.

Locke, John. An Essay concerning Human Understanding. 1690. Ed. Alexander Campbell Fraser. Oxford: Oxford U P, 1895. 2 vols.

McKeon, Michael. The Origins of the English Novel 1600-1740. Baltimore: Johns Hopkins U P, 1987.

Paulson, Ronald, ed. Fielding: A Collection of Critical Essays. Englewood Cliffs: PrenticeHall, 1962. . Satire and the Novel in Eighteenth-Century England. New Haven: Yale U P, 1967.

Powers, Lyall. 'The Influence of the Æneid on Fielding's Amelia.' Modern Language Notes 71 (1956): 330-336.

Rawson, Claude. 'Henry Fielding.' The Cambridge Companion to the Eighteenth-Century Novel. Ed. John Richetti. Cambridge: Cambridge U P, 1996. 120-152.

Richardson, Samuel. Clarissa. Or, The History of a Young Lady: Comprehending the Most Important Concerns of Private Life. 1747-48. London: Printed for S. Richardson ... and Sold by A. Millar, 1748 [sic]. 7 vols.

. Clarissa: Preface, Hints of a Preface, and Postscript. Ed. R. F. Brissenden. Los Angeles: Augustan Reprint Society, 1964.

A Collection of the Moral and Instructive Sentiments, Maxims, Cautions, and Reflections Contained in the Histories of Pamela, Clarissa, and Sir Charles Grandison. London: Printed for S. Richardson ... and Sold by Andrew Millar, 1755.

. The Correspondence of Samuel Richardson. Ed. Anna Laetitia Barbauld. London: Phillips, 1804. 6 vols.

. Letters and Passages Restored from the Original Manuscripts of the History of Clarissa.

London: Printed for S. Richardson ... and Sold by Andrew Millar, 1751.

Selected Letters of Samuel Richardson. Ed. John Carroll. Oxford: Clarendon Press, 1964.

Sabor, Peter. 'Amelia and Sir Charles Grandison: The Convergence of Fielding and Richardson.' Wascana Review 17 (Fall 1982): 3-18. 
Sherburn, George. 'Fielding's Amelia: An Interpretation.' 1936. Ed. Ronald Paulson. Fielding: A Collection of Critical Essays. Englewood Cliffs: Prentice-Hall, 1962. 146-157.

Thomas, D. S. 'Fortune and the Passions in Fielding's Amelia.' Modern Language Review 60 (1965): 176-187.

Thornbury, E.M. Appendix. Henry Fielding's Theory of the Comic Prose Epic. 1931. New York: Russell and Russell, 1966. 168-189.

Van Marter, Shirley. 'Richardson's Revisions of Clarissa in the Second Edition.' Studies in Bibliography 26 (1973): 105-132.

.'Richardson's Revisions of Clarissa in the Third and Fourth Editions.' Studies in Bibliography 28 (1975): 119-152.

Wolff, Cynthia Griffin. 'Fielding's Amelia: Private Virtue and Public Good.' Texas Studies in Language and Literature 10 (1968): 37-55.

\section{Notes}

1 Parenthetical references to the novel cite The Wesleyan Edition of the Works of Henry Fielding: Amelia, ed. Martin C. Battestin and Fredson Bowers (Oxford: Clarendon Press, 1983).

2 As in all of Fielding's novels, 'Fortune' and 'Providence' hold special significance in the construction of character and in the narrator's speculative vocabulary. D. S. Thomas devotes an article to establishing the classical roots of Fielding's use of these terms in Amelia. Toward the conclusion of his paper, he suggests: 'There is an interesting example of [the terms'] double usage in Amelia. When at last justice is done and Amelia and Booth receive their rewards, Dr. Harrison as a theologian attributes this to Providence [(517)]. Fielding, speaking as a novelist, expresses a similar view in the final chapter but uses the term "Fortune."' (183) In Amelia, Fielding revised his earlier sense of mortal passivity in the face of an unblinking personification of Fortune. In the closing pages of Jonathan Wild (1743), he argued (perhaps ironically) that 'to struggle against that lady's decrees is vain and impotent; and whether she hath determined you shall be hanged or be a prime minister, it is in either case lost labour to resist' (212). For further detailed references to instances which support the argument that 'characters in Amelia often believe they are at the mercy of adamant impersonal causes,' see Braudy 204-212. See also Battestin's notes to Amelia 15 and 87. Several feminist critics have linked Amelia's high moral conscience with a curious inability to make actual decisions to improve effectively her family's difficulties; Cynthia Griffin Wolff has argued that 'Amelia's virtue is private, and its influence can be felt only in personal interaction' (54), and Alison Conway adds: 'it seems that even privately Amelia can effect very little change' (45).

3 When Fielding defended Amelia in his mock 'Court of Censorial Enquiry' three weeks following Amelia's publication, he held to his high pedagogic purpose and strong sense of paternal responsibility for the novel's 'Education' and 'Conduct,' with particular respect to his use of Virgil as its 'noble model': 'I followed the Rules of all those who are acknowledged to have writ best on the Subject; and if her Conduct be fairly examined, she will be found to deviate very little from the strictest Observation of all those Rules; neither Homer nor Virgil pursued them 
with greater Care than myself, and the candid and learned Reader will see that the latter was the noble model, which I made use of on this Occasion.'

(Covent-Garden 28 Jan. 1752, 65) Lyall Powers has tried to chart the analogy between Virgil's Æneid and Amelia; despite the dubious success of an 'adherence to the Æneid' (335), the intertextual intention - its opening in medias res and its noble wish to record the 'History' of nationally emblematic 'Accidents' indicates Fielding's deeply self-conscious didactic project. For detailed accounts of the novel's hostile reception upon its release on 19 December 1751, see Paulson ed., Fielding 286-336, 345-351, and Battestin, Amelia l-lvii.

4 This paper cites the 1747-48 edition of Clarissa since it is with this edition that Fielding had been best acquainted. Only the third edition (1751) offers significant variations from the first, and it is doubtful that Fielding would have had the time or physical energy during 1750-1, two years of serious illness and overwork, to have reread Richardson before December 1751, when Amelia was published.

5 Despite his promise, Fielding provided notes for a revised edition of the novel, although we do not have any records of the context in which they were produced or intended to be used. This second edition was not published until 1762: it appeared in Arthur Murphy's The Works of Henry Fielding, Esq.: with the Life of the Author (London: Printed for A. Millar), 4 vols (Dudden 1137).

6 John Carroll, along with Mark Kinkead-Weekes and Leslie Stephen in his entry on Richardson in the 1898 edition of the $D N B$, argues that this preface was is fact written by Warburton $(85,165)$. Richardson wrote to Warburton on 19 April 1748: 'I am infinitely obliged to you, sir, for your Papers. But how shall I take it upon myself? I must, if put to me, by Particulars, suppose it to be suggested to me, at least, by some Learned Friend, so disguising as you may not be suggested to be the Person. And I have transcribed it, that not even my compositor may guess at the Author - But it is really so much above my learning and ability, that it will not be supposed mine by anybody.' (Selected Letters 85 )

7 Richardson's Letters and Passages Restored was published simultaneously with the third edition of Clarissa in 1751, emphasizing the differences between the editions (Van Marter 1975, 119).

8 Shirley Van Marter explains that 'another large set of revisions systematically alters various terms of address throughout the second edition.' She continues: 'One of the most obvious patterns is the disappearance of Clarissa's childlike use of "mamma" and "papa." In 1749 Richardson consistently replaced these two words with the more restrained greeting "Mother" and "Father."' $(1973,112)$ Fielding was aware of the class associations with these words; see Joseph Andrews 4.7 where Pamela Booby drops 'mother and father' in favour of 'mamma and papa' when declaring 'I am no longer Pamela Andrews; I am now this gentleman's lady' (327).

9 Hume emphasized this correspondence to his other works in a letter to his fellow scholar and longtime friend Gilbert Elliot: 'I believe the philosophical Essays contain every thing of Consequence relating to the Understanding, which you would meet in the Treatise \& I give you my advice against reading the latter. By shortening and simplifying the Questions, I really render them more complete.' (Letters 1,158) The Philosophical Essays is listed - albeit with a slightly mistaken title - in the Catalogue of Fielding's library, item 539 (Thornbury 185). Since 1758, Philosophical Essays concerning Human Understanding has been known as An Enquiry concerning Human Understanding. In the Postscript to Battestin's paper 
that traces 'a drama residing in Fielding's anxious response to a new and particularly disturbing species of philosophical scepticism,' 'whose formidable champion was David Hume,' he offers very convincing evidence that Fielding was aware of Hume's writing during the 1740s, given the overlap in Hume's and Fielding's respective social circles ('The Problem of Amelia' 617, 616).

10 Hume's coy allusion refers to this passage in the Essay in which Locke relates ethical propriety to mathematical certainty: 'Where there is no property, there is no injustice, is a proposition as certain as any demonstration in Euclid: for the idea of property being a right to any thing; and the idea to which the name injustice is given, being the invasion or violation of that right; it is evident that ... I can as certainly know this proposition to be true, as that a triangle has three angles equal to two right ones.' (4.3.18, II 208) 